\title{
BANKING LEVERAGE, CREDIT INDICATORS, CURRENT ACCOUNT BALANCE AND ECONOMIC GROWTH WITH THEIR IMPLICATIONS IN TURKEY (1999-2013)
}

\author{
Göksel TİRYAKİ
}

\begin{abstract}
The influence of credit indicators, such as Banking Leverage, Credit Growth Rate, Credit/Deposit and Non-performing Loans Ratios over growth rate of Gross Domestic Product (GDP) and Current Account Balance are both very substantial and argumentative matters for financial economics literature. In this study, the importance of these credit indicators over two main parameters of macroeconomic environment is analyzed. According to the analysis results, credit indicators are more influential and show more causality over current account balance than GDP. On the other hand Banking Leverage is more influential and shows more causality over current account balance and GDP than other credit indicators. As for policy implications, our findings implies that banking leverage is more effective regulation and policy tool as macro prudential measures and targets in order to sustain financial stability than other credit indicators.
\end{abstract}

Keywords: Credit Indicators, Credit Growth, Banking Leverage, GDP Growth, Current Account Balance

Jel Codes: E00, G00, G10, G21

\section{TÜRKIYYE'DE 1999-2013 VERILLERI IŞIĞINDA BANKALARIN KALDIRAÇ ORANI, KREDİ GÖSTERGELERI, CARİ HESAP DENGESI VE EKONOMİK BÜYÜME}

Öz

Kaldıraç, Kredi Büyümesi, Kredi/Mevduat ve Kredi Takip Oranı gibi göstergelerin Gayri Safi Yurtiçi Hasıla (GSYH) büyümesi ve Cari Hesap Dengesi (Cari Açı) üzerinde ne kadar etkili ve bunlarla ne kadar ilişkili olduğu finansal ekonomi literatüründe ciddi şekilde tartışılmaktadır. Bu çalışmada, söz konusu kredi göstergelerinin sözünü ettiğimiz iki temel makro ekonomik değişken üzerindeki önemi analiz edilmiştir.

* Dr., Senior Bank Examiner, Banking Regulation and Supervision Agency of Turkey, gtiryaki@bddk.org.tr 
Yaptığımız çalışma sonucuna göre, kullandığımız kredi göstergeleri Cari Hesap Dengesi (Cari Açık) ile GSYH büyümesine göre daha fazla ilişki ve nedensellik göstermiştir. Bankaların Kaldıraç Oranı da diğer kredi göstergelerine nazaran hem Cari Hesap Dengesi (Cari Açık) hem de GSYH büyümesi açısından daha fazla önem arz etmiştir. Bu nedenle finansal istikrarın desteklenmesi amacıyla bankaların Kaldıraç Oranının bir politika aracı ve hedefi olarak kullanılmasının diğer kredi göstergelerine kıyasla daha etkin bir yöntem olacağı sonucuna ulaşılmaktadır.

Anahtar Kelimeler: Kredi Göstergeleri, Kredi Büyümesi, Kaldıraç, GSYH Büyümesi, Cari Hesap Dengesi

Jel Kodları: E00, G00, G10, G21

\section{Introduction}

The importance of financial system and development has been accepted by the many financial researchers and scholars since 1990s (Campos and Dercon, 2014, 1-2). The essential part of financial system is financial intermediaries (deposit and credit). The credit is one of the crucial tools in order to support economic activities. Banks are the main credit and loan source for the all agents of the economy. Therefore, the relationship between credit (banking loans) and growth is one of the major research fields of financial economics. Also recently the relationship between current account balance and the aggregate credit has become an interesting topic for analyst and researchers.

In term of supporting consumption and investment, banking loans are vital funding sources. However, excessive credit demand and expansion of banking loans are accepted as a fragility indicator for both financial system and the general economy. Therefore the level of total credits relative to GDP and household income are very popular research items recently in the financial and economic world.

On the other hand, especially the level of optimal banking leverage is one of the recent financial regulation area and research topics after 2007-2009 global financial crises (Tiryaki, 2010, 118-122). The main purpose of Basel Banking Supervision Committee with Basel III rules is to support and sustain banks' equity and to restrict banking leverage to ensure financial stability. However there is no consensus in the level of optimal leverage for banks in order to achieve a balance between the safety and the intermediary's function of financial system (Miles, 2011, 1-2).

According to financial economics literature, there are two main consequences of banking leverage over general economy and financial system that derive attention. One of them is related to macro economical conditions, especially over total economic activities and its impacts. Another one is about its effects on financial system in terms of its safety and function. In this study, macro economical effects of banking leverage and other credit indicators over such as economic growth and current account are examined in terms of Turkish experience based on quarterly data set of 1999-2013 periods. 


\section{Literature Review}

Banking credits or loans are very popular and arguable topic in financial economics. Particularly financial crises are the most related subject of banking credits. The notion that credit booms provoke financial instability is not new; it has been argued and analyzed since the works of Minsky and Kindleberger in the late 1970's. However, according to Schularick and Taylor (2009, 14) "Yet statistical evidence is still relatively scant".

After Reinhart and Kaminsky $(1999,40)$ examined "the similarities and common patterns across crises" based on the data set of 76 currency crises and 26 banking crises, they found that banking (financial) and currency crises are nearly connected to financial liberalization and closely interconnected with each other. When both crises happen together, the results are more severe economically. They mentioned for both crises that "a financial shock, possibly financial liberalization or increased access to international capital markets, appear to activate a boom-bust cycle by providing easy access to financing" (Reinhart and Kaminsky, 1999, 39). Therefore "easy access to financing" is one of the major reasons of financial crises and today, banking loans are one of the main financial intermediaries for "easy access to financing".

Schularick and Taylor $(2009,1-2,14)$ examined the role of credit based on wide historical dataset for 14 countries over the years 1870-2008. They exhibited that "leverage in the financial sector has increased strongly in the second half of the twentieth century as shown by a decoupling of money and credit aggregates". They conclude that the importance of credit was ignored by policymakers and researchers over the history and the levels of total credits include very useful information for potential financial crises in spite of not being a perfect predictor. However, "in some periods, especially in eras of financial development and innovation, credit expands to support real economic gains."

The paper of Jorda, Schularick and Taylor (2010, 36-37) presents that credit growth provides better prognostic signs than current accounts in term of financial instability. However the link between credit growth and current accounts has become more apparent in recent decades. Therefore high credit expansions with severe current account imbalances generate strong risks of instability in an open economy with free capital mobility.

The study of Jorda, Schularick and Taylor (2011, 37-38) has important consequences about credit, leverage and crisis based on the wide data set with over 200 recession episodes in 14 advanced countries between 1870 and 2008. They basically conclude that financial crisis recessions are more costly than normal recessions, so they analyze "how past credit accumulation impacts the behavior of not only output but also other key macroeconomic variables such as investment, lending, interest rates, and inflation". Therefore they indicate that the lending power of financial factors (system) has a substantial function in the modern business cycle. They summarize that "potential explanations for these effects include the possibility that financial accelerator effects are larger with more leveraged balance sheets; that debt-overhang pressures are more acute after credit-intensive booms; or that expectational shifts have more serious effects when credit intensity has risen in a more extreme fashion." 
Elekdag and $\mathrm{Wu}(2011,19)$ analyzed 99 credit booms, 60 of them in emerging economies. They found two important results: loose macroeconomic policy provokes the likelihood of credit booms and large capital flows and domestic monetary conditions are important in terms of real credit growth.

According to their analysis based on data for 77 countries for the period 1973-2009, Amri, Prabha, and Wihlborg (2012, 1-2) exhibit that not in all cases but many episodes of high credit growth trigger some kind of banking or financial crises. The essential imbalances and problems of financial systems increase the risk of banking crises because of high credit growth. They also determine that the indicators of potential fragility for financial system are "high leverage, financial liberalization, a high rate of capital inflows (e.g. bank loans) from abroad, surges in asset prices, the existence of explicit or implicit protection of banks' creditors, and weak supervision of banks' risk-taking." Their hypotheses "focused on financial fragility as an economic condition that is likely to increase the probability that high credit growth is followed by a banking crisis." One of their important consequences is the independent effect of high credit growth is strong for substantially advanced economies, however "the independent and the interactive effects of the financial fragility factors" are changeable relative to countries and period of time.

Amri, Prabha and Wihlborg $(2012,24-25)$ conclude that leverage has a robust positive effect over the amplification of the impact of credit growth in advanced economies. They indicate that credit growth and the financial fragility indicators can be used as macro-prudential signal for banking crises in especially advanced economies. Therefore regulators should take into account high credit growth and financial fragility indicators such as leverage, weak capital regulation and supervision and asset inflation to sustain and monitor financial stability.

After 2008-2009 global financial recession, Taylor (2012, 8-13) make a useful summary about the relationship between the banking system, financial crises, and economic performance. According to his work, supreme leverage (size of the banking sector) presents "unprecedented lessons". One of them is that former credit growths include "valuable predictive information" about future's potential crises.

Also Leitao (2012, 262-263) finds that savings and health of banking system are more significant than banking credit over economic growth, because "credit growth can generate a weak banking system".

Nuno and Carlos $(2013,21)$ also present some important implications about leverage cycles of financial intermediaries in the United States. They found that changes in leverage, equity and total assets of financial intermediaries have generally the same dimension and these fluctuations can be more volatile than GDP's. Specifically leverage causes, more than equity, changes in total assets. Also they say that "leverage is positively correlated with total assets and GDP, and negatively correlated with equity."

Lane and McQuade $(2013,3,20)$ analyzed the relations between international capital flows and domestic credit growth during the 2003-2008 European experience. They concluded that the current account balance is a misleading indicator in understanding the relation between international 
capital flows and domestic credit growth based on the differences in the domestic credit growth, net debt and equity flows. "Moreover, it is striking that net debt flows appears to be the relevant measure, with no apparent gain to splitting net debt flows between gross debt inflows and gross debt outflows. The apparent empirical connection between net international debt flows and domestic credit growth calls for analytical models that can capture this relation." Also they presents that there is an important global dimension to the determination of national domestic credit growth and external imbalances.

Ganioğlu (2013, 19-20) also concluded that credit expansions in developed countries and current account imbalances in developing countries are more significant as financial crisis indicators.

Another important study about relationship between quarterly credit and GDP growth based on the Turkish data belongs to Ermişoğlu, Akçelik and Oduncu (2013, 14-15). This paper shows that credit expanding numbers can play a strong role in terms of explaining the pattern of GDP growth. Therefore they concluded that credit data has a substantial impact over GDP growth.

Also a specific research of Telatar $(2011,32-33)$ related to causality between credits and current account deficit in Turkey presents interesting consequences about relationship between credits and current account deficit. According to this study, there is no meaningful connection between total credit and current account deficit, but there is a positive relationship of causality from consumer credits to current account deficit.

On the other hand, there are some different opinion and research results against dominant view about the effects of banking credits. After they examine the data of 39 financial crises, Takats and Upper $(2013,1,18)$ "find that declining bank credit to the private sector will not necessarily constrain the economic recovery after output has bottomed out following a financial crisis." However their findings are specifically related to first two years after financial crisis resulting from credit booming.

\section{Analysis and Models}

\section{I. General}

In this study, Turkey's quarterly data of 1999-2013 periods are put in analysis. Four important credit indicators calculated from the Balance Sheets of Turkish Banking System are selected. These credit indicators are Banking Leverage (Banking Leverage Ratio is based on legal definitions of banking regulations :(Banks' Assets $+(0,5 \mathrm{xNon}$-cash Credit and Guaranty) $+(0,01 \times$ Derivatives $)) /$ Banks' Equity), Change in Banking Leverage, Credit/Deposit and Non-performing Loans Ratios (NPL) and Credit Growth Rate. Two main macroeconomic parameters (GDP Growth and Current Account Balance) with these indicators of credit are separately modeled. Thus, the importance of these credit indicators over two main parameters of macroeconomic environment is analyzed.

These credit indicators are modeled to represent different point of views related to overall credit information in banking system. Banking Leverage Ratio exhibits the trend of equity compared 
to total asset and important off-balance sheets items of banking system. More specifically, Credit Growth Rate presents direct occurrences in loan portfolio of banking, Non-performing Loans Ratio, on the other hand, reflects negative advents in total credit in banking sector. Also, Credit/ Deposit Ratio shows the level of direct funding and connection of credit with deposit. Therefore, these four ratios can be used as strong indicators for measuring effects of credits through the banking system. Besides, Change of Banking Leverage Ratio with its values of previous year's same quarter illustrates another dimension of leverage in our analysis.

As known, GDP Growth Rate and Current Account Balance/GDP are two main economic variables in order to gauge macroeconomic stability for a country. In terms of Turkey, unstable GDP Growth Rate and Current Account Balance/GDP are especially structural problems in many times. Thus, these two parameters can be meaningful as separate the dependent variables in our analysis in order to measure the impacts of credits based on our selected credit indicators.

\subsection{Variables}

This study mainly aims to analyze GDP Growth Rate and Current Account Balance/GDP separately with four fundamental credit indicators. Therefore four main credit and financial intermediary indicators calculated from total balance sheet of the Turkish Banking System are used in order to show relationship and connection among credit, current account balance and economic growth based on Turkish experience. Before this analysis, standardized graphs of these credit indicators with GDP Growth Rate and Current Account Balance/GDP are presented below in order to exhibit visual patterns among parameters.

Graph I: GDP and Leverage

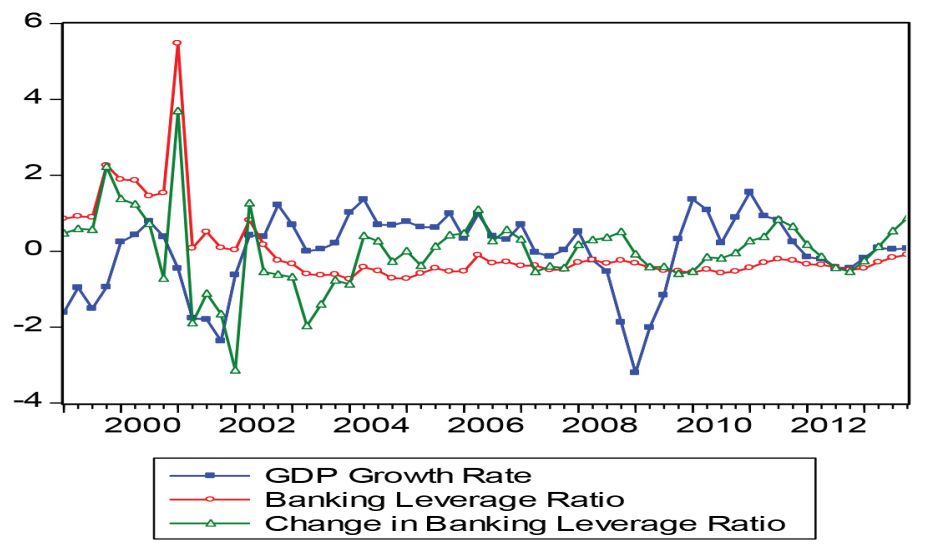

Source:

Banking Regulation and Supervision Agency of Turkey (BRSA) (20I4), Statistical Data, http:// www.bddk.org.tr/WebSitesi/turkce/lstatistiki_Veriler/lstatistiki_Veriler.aspx (I5.04.20I4) Turkish Banking Association (TBA) (20l4), Statistical Reports, http://www.tbb.org.tr/tr/ Banka_ve_Sektor_Bilgileri/Tum_Raporlar.aspx (15.04.2014)

Central Bank of the Republic of Turkey (CBRT) (20I4), Electronic Data Distribution System, http://evds.tcmb.gov.tr/cbt.html (30.04.20I4) 
Graph 2: GDP and Credit

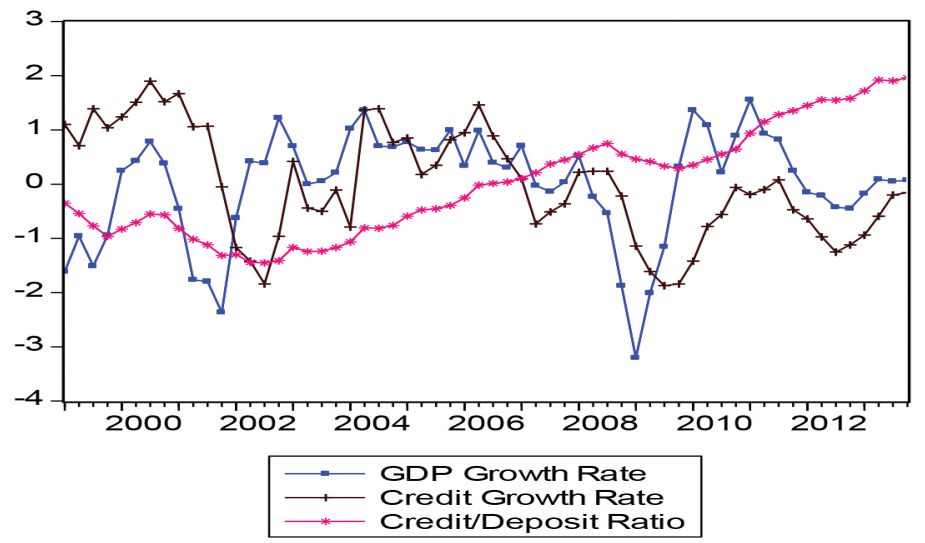

Source:

Banking Regulation and Supervision Agency of Turkey (BRSA) (20I4), Statistical Data, http:// www.bddk.org.tr/WebSitesi/turkce/lstatistiki_Veriler/Istatistiki_Veriler.aspx (I5.04.20I4)

Turkish Banking Association (TBA) (2014), Statistical Reports, http://www.tbb.org.tr/tr/ Banka_ve_Sektor_Bilgileri/Tum_Raporlar.aspx (15.04.2014)

Central Bank of the Republic of Turkey (CBRT) (2014), Electronic Data Distribution System, http://evds.tcmb.gov.tr/cbt.html (30.04.20I4)

Graph 3: GDP, Current Account and NPL

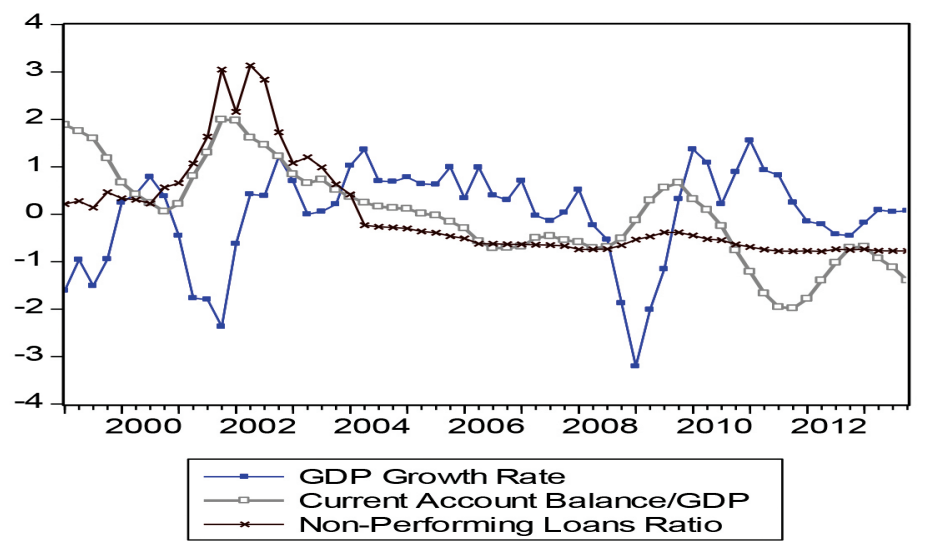

\section{Source:}

Banking Regulation and Supervision Agency of Turkey (BRSA) (20I4), Statistical Data, http:// www.bddk.org.tr/WebSitesi/turkce/lstatistiki_Veriler/Istatistiki_Veriler.aspx (I5.04.20I4)

Turkish Banking Association (TBA) (20I4), Statistical Reports, http://www.tbb.org.tr/tr/ Banka_ve_Sektor_Bilgileri/Tum_Raporlar.aspx (15.04.2014)

Central Bank of the Republic of Turkey (CBRT) (2014), Electronic Data Distribution System, http://evds.tcmb.gov.tr/cbt.html (30.04.20I4) 
Graph 4: Current Account and Leverage

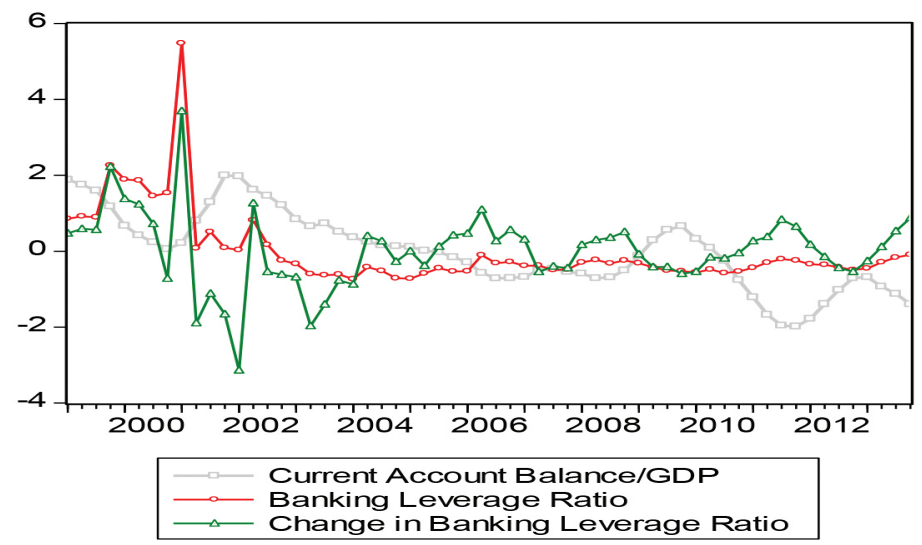

Source:

Banking Regulation and Supervision Agency of Turkey (BRSA) (20I4), Statistical Data, http:// www.bddk.org.tr/WebSitesi/turkce/lstatistiki_Veriler/lstatistiki_Veriler.aspx (I5.04.20 I4)

Turkish Banking Association (TBA) (20I4), Statistical Reports, http://www.tbb.org.tr/tr/ Banka_ve_Sektor_Bilgileri/Tum_Raporlar.aspx (I5.04.20I4)

Central Bank of the Republic of Turkey (CBRT) (20l4), Electronic Data Distribution System, http://evds.tcmb.gov.tr/cbt.html (30.04.2014)

Graph 5: Current Account and Credit

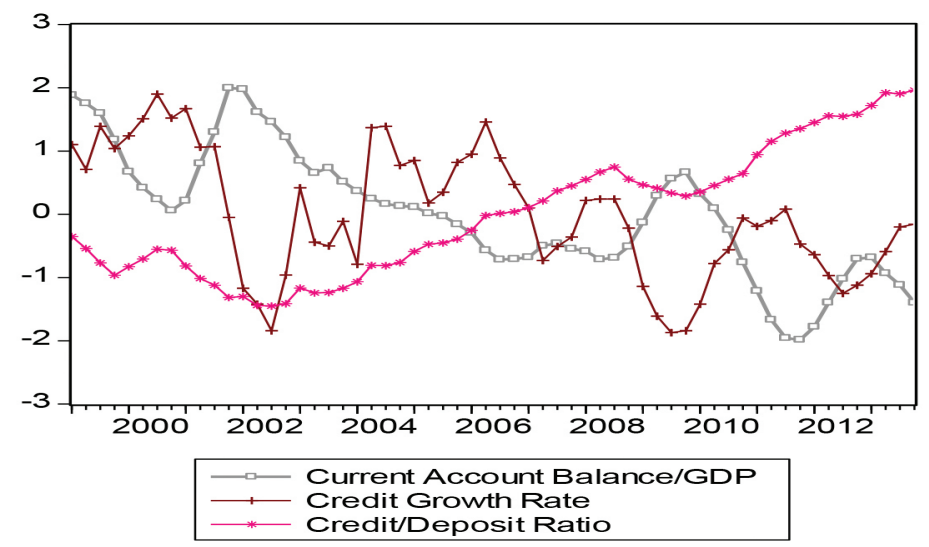

\section{Source:}

Banking Regulation and Supervision Agency of Turkey (BRSA) (20I4), Statistical Data, http:// www.bddk.org.tr/WebSitesi/turkce/lstatistiki_Veriler/lstatistiki_Veriler.aspx (I5.04.20I4)

Turkish Banking Association (TBA) (20I4), Statistical Reports, http://www.tbb.org.tr/tr/ Banka_ve_Sektor_Bilgileri/Tum_Raporlar.aspx (I5.04.20I4)

Central Bank of the Republic of Turkey (CBRT) (20I4), Electronic Data Distribution System, http://evds.tcmb.gov.tr/cbt.html (30.04.20I4) 
As seen from above graphs, it is clear that especially credit growth rate has a very similar visual pattern with GDP growth and current account balance relative to other credit indicators. The graphical pattern of Credit Growth Rate has comparatively same direction with GDP Growth Rate and reverse direction with Current Account Balance/GDP. Also Change in Banking Leverage Ratio presents quite similar pattern positively with GDP and negatively with current account. Although other credit indicators occasionally exhibit positive and negative graphical patterns with GDP and current account balance, there is no substantial and stable visual relationship among these variables. Additionally, correlation matrix of all these variables is given below.

Table I: Correlation Matrix of All Variables

\begin{tabular}{|l|c|c|c|c|c|c|c|}
\hline & $\begin{array}{c}\text { GDP } \\
\text { Growth } \\
\text { Rate }\end{array}$ & $\begin{array}{c}\text { Current } \\
\text { Account } \\
\text { Balance/ } \\
\text { GDP }\end{array}$ & $\begin{array}{c}\text { Banking } \\
\text { Leverage } \\
\text { Ratio }\end{array}$ & $\begin{array}{c}\text { Change in } \\
\text { Banking } \\
\text { Leverage } \\
\text { Ratio }\end{array}$ & $\begin{array}{c}\text { Credit } \\
\text { Growth } \\
\text { Rate }\end{array}$ & $\begin{array}{c}\text { Credit/ } \\
\text { Deposit } \\
\text { Ratio }\end{array}$ & $\begin{array}{c}\text { Non- } \\
\text { Performing } \\
\text { Loans Ratio }\end{array}$ \\
\hline $\begin{array}{l}\text { GDP Growth } \\
\text { Rate }\end{array}$ & 1.000000 & -0.317221 & -0.188966 & 0.142658 & 0.087202 & 0.019813 & -0.187632 \\
\hline $\begin{array}{l}\text { Current Account } \\
\text { Balance/GDP }\end{array}$ & -0.317221 & 1.000000 & 0.301244 & -0.256622 & 0.093251 & -0.824470 & 0.783888 \\
\hline $\begin{array}{l}\text { Banking } \\
\text { Leverage Ratio }\end{array}$ & -0.188966 & 0.301244 & 1.000000 & 0.601111 & 0.479251 & -0.291858 & 0.300904 \\
\hline $\begin{array}{l}\text { Change in } \\
\text { Banking } \\
\text { Leverage Ratio }\end{array}$ & 0.142658 & -0.256622 & 0.601111 & 1.000000 & 0.428405 & 0.179921 & -0.303627 \\
\hline $\begin{array}{l}\text { Credit Growth } \\
\text { Rate }\end{array}$ & 0.087202 & 0.093251 & 0.479251 & 0.428405 & 1.000000 & -0.329060 & -0.033423 \\
\hline $\begin{array}{l}\text { Credit/Deposit } \\
\text { Ratio }\end{array}$ & 0.019813 & -0.824470 & -0.291858 & 0.179921 & -0.329060 & 1.000000 & -0.764374 \\
\hline $\begin{array}{l}\text { Non-Performing } \\
\text { Loans Ratio }\end{array}$ & -0.187632 & 0.783888 & 0.300904 & -0.303627 & -0.033423 & -0.764374 & 1.000000 \\
\hline
\end{tabular}

Source:

Banking Regulation and Supervision Agency of Turkey (BRSA) (2014), Statistical Data, http://www.bddk.org.tr/WebSitesi/ turkce/lstatistiki_Veriler/lstatistiki_Veriler.aspx (I5.04.20I4)

Turkish Banking Association (TBA) (2014), Statistical Reports, http://www.tbb.org.tr/tr/Banka_ve_Sektor_Bilgileri/Tum_ Raporlar.aspx (15.04.2014)

Central Bank of the Republic of Turkey (CBRT) (20/4), Electronic Data Distribution System, http://evds.tcmb.gov.tr/cbt.html $(30.04 .2014)$

According to above correlation matrix, the credit indicators are more correlated with Current Account Balance/GDP than GDP Growth Rate. Particularly, Credit/Deposit Ratio and NPL Ratio are highly correlated with current account balance relative to other credit indicators. Interestingly, Leverage and Change in Leverage Ratios present low and negative correlations with GDP growth and current account balance. Also Credit Growth Rate has one of the lowest levels of correlation with GDP growth and current account balance compared to other credit indicators. 


\subsection{Results of Models}

\subsection{I.GDP and Credit Indicators}

In this section, first, it is examined what kind of effects credit indicators have on GDP Growth Rate (GDP). Therefore Granger casualties with credit indicators over GDP are expected to gauge separately. In estimating models including time series variables, the first thing to do is to make sure whether all variables in the model are stationary. Since many financial and economic parameters include time series data, they are generally non-stationary series. Therefore, testing unit root analysis regarding time series before doing any econometric analysis with these parameters is necessary. In order to make unit root analysis, Augmented Dickey-Fuller (ADF), KwiatkowskiPhillips-Schmidt-Shin (KPSS) and Phillips-Perron tests are used with all time series. Unit root tests with intercept and trend based on characteristic structure of time series are conducted by using E-views program. Unit Root test results are presented below in Table 2.

Table 2: Unit Root Test Results

\begin{tabular}{|l|c|c|c|}
\hline Time Series & ADF & KPSS & Phillips-Perron \\
\hline GDP Growth Rate (gdp) & $-3.75^{* * *}$ & 0.12 & -3.03 \\
\hline Current Account Balance (cab) & $-5.54^{* * *}$ & 0.05 & -2.84 \\
\hline Banking Leverage Ratio (lev) & -2.41 & $0.54^{* *}$ & $-3.92^{* * *}$ \\
\hline Change in Banking Leverage Ratio (chglev) & -2.57 & 0.10 & $-6.15^{* * *}$ \\
\hline Credit Growth Rate (credit) & -2.25 & $0.49^{* *}$ & -2.65 \\
\hline Difference of Credit (d(credit)) & $-6.09^{* * *}$ & 0.05 & $-7.14^{* * *}$ \\
\hline Credit/Deposit Ratio^ (credep) & -2.07 & $0.17^{* *}$ & -2.72 \\
\hline Difference of Credep (d(credep)) & $-4.56^{* * *}$ & 0.11 & $-4.53^{* *}$ \\
\hline Non-performing Loans Ratio (npl) & -1.22 & $0.56^{* *}$ & -1.48 \\
\hline Difference of NPL (d(npl)) & $-7.65^{* * *}$ & 0.08 & $-7.73^{* * *}$ \\
\hline
\end{tabular}

*, **, ***, Unit root hypotheses are rejected by $\% 99, \% 95$ and $\% 90$ confidence intervals. ${ }^{\wedge}$ Time series of Credep is seasonally adjusted.

\section{Source:}

Banking Regulation and Supervision Agency of Turkey (BRSA) (2014), Statistical Data, http://www.bddk.org.tr/WebSitesi/ turkce/Istatistiki_Veriler/Istatistiki_Veriler.aspx (I5.04.20I4)

Turkish Banking Association (TBA) (2014), Statistical Reports, http://www.tbb.org.tr/tr/Banka_ve_Sektor_Bilgileri/Tum_ Raporlar.aspx (I5.04.20I4)

Central Bank of the Republic of Turkey (CBRT) (20I4), Electronic Data Distribution System, http://evds.tcmb.gov.tr/cbt.html (30.04.20I4)

As seen from Table 2, Credit, Credep and NPL have unit root, meaning that they do not comply with being stationary rule to make a meaningful econometric analysis. However, these three variables can be stationary by taking first differences of the data. After obtaining stationary series for all variables, conducting the econometric analysis in order to examine the impacts of our credit indicators over economic growth and current account balance is feasible. 
Estimating vector auto regressive (VAR) is one of the main econometric analysis tools for presenting relationships among variables. Therefore, VAR models for these variables are modeled separately, taking and $\mathrm{CAB}$ as dependent variable in order to show the direction of probable relations. Also, potential Granger causalities among these variables are calculated separately to check the causality between economic growth, current account and credit indicators. Therefore regression analysis for every credit indicator with GDP and $\mathrm{CAB}$ as dependent variable is our main modeling tool in this study. Also $\mathrm{H} 0$ hypothesis is fundamentally used in order to test statistically whether each credit indicator is significant as a Granger cause over GDP and CAB or not .

To an estimate a VAR model, proper number of lag has to be determined. Akaike Information Criterion (AIC) and Schwarz Information Criteria (SIC) are two main methods in order to find a proper number of lag. Thus, VAR estimations are made for every number of first 5 lags. All Granger test results are submitted in below tables for each number of lag up to 5 .

All time series, except Credep, do not have any seasonality. Therefore time series of Credit/ Deposit Ratio is deseasonalized in our all models. However, as seen from above graphs there are a very high volatility in 2000 and 2001's some periods of Lev and Chglev time series. That's dummy variables are used for these periods of very high volatility while including Lev and Chglev time series in our models.

\subsection{I.I.GDP Growth Rate and Banking Leverage Ratio}

First credit and financial intermediary indicator for analyzing with GDP Growth Rate is Leverage Ratio of The Turkish Banking System. Granger Causality Test Results for this variable are given below Table 3 .

Table 3: Granger Causality Test Results for GDP and Banking Leverage Ratio

\begin{tabular}{|c|c|c|c|c|}
\hline \multicolumn{5}{|c|}{ Dependent variable: GDP } \\
\hline Excluded & Chi-sq & Negative/Positive (Coefficients) & Lag Number & Probability \\
\hline Lev & 7.376382 & $(-)$ & 1 & $0.0066^{*}$ \\
\hline Lev & 7.391236 & $(-)$ & 2 & $0.0248^{\star *}$ \\
\hline Lev & 10.70963 & $(-)$ & 3 & $0.0134^{\star *}$ \\
\hline Lev & 14.47700 & $(-)$ & 4 & $0.0059^{*}$ \\
\hline Lev & 14.98565 & $(-)$ & 5 & $0.0104^{\star *}$ \\
\hline
\end{tabular}

*, **, Parameters are statistically significant by $\% 99$ and $\% 95$ confidence intervals.

\section{Source:}

Banking Regulation and Supervision Agency of Turkey (BRSA) (20I4), Statistical Data, http://www.bddk.org.tr/WebSitesi/ turkce/Istatistiki_Veriler/Istatistiki_Veriler.aspx (I5.04.20I4)

Turkish Banking Association (TBA) (2014), Statistical Reports, http://www.tbb.org.tr/tr/Banka_ve_Sektor_Bilgileri/Tum_ Raporlar.aspx (15.04.2014)

Central Bank of the Republic of Turkey (CBRT) (20I4), Electronic Data Distribution System, http://evds.tcmb.gov.tr/cbt.html (30.04.2014) 
Banking Leverage Ratio affects GDP Growth Rate negatively for each numbers of lag. Also very low levels of probability show that the relationship between variables is statistically significant.

\subsection{I.2. GDP Growth Rate and Change in Banking Leverage Ratio}

The impact of change in leverage over GDP is modeled secondly. Results are below.

Table 4: Granger Causality Test Results for GDP and Change in Banking Leverage Ratio

\begin{tabular}{|c|c|c|c|c|}
\hline \multicolumn{7}{|c|}{ Dependent variable: GDP } \\
\hline Excluded & Chi-sq & $\begin{array}{c}\text { Negative/Positive } \\
\text { (Coefficients) }\end{array}$ & Lag Number & Probability \\
\hline ChgLev & 9.721630 & $(-)$ & 1 & $0.0018^{*}$ \\
\hline ChgLev & 7.308802 & $(-)$ & 2 & $0.0259^{* *}$ \\
\hline ChgLev & 14.04644 & $(-)$ & 3 & $0.0028^{*}$ \\
\hline ChgLev & 13.58019 & $(-)$ & 4 & $0.0088^{*}$ \\
\hline ChgLev & 14.33413 & $(-)$ & 5 & $0.0136^{* *}$ \\
\hline
\end{tabular}

*, **, Parameters are statistically significant by $\% 99$ and $\% 95$ confidence intervals.

Source:

Banking Regulation and Supervision Agency of Turkey (BRSA) (20I4), Statistical Data, http://www.bddk.org.tr/WebSitesi/ turkce/Istatistiki_Veriler/Istatistiki_Veriler.aspx (15.04.20I4)

Turkish Banking Association (TBA) (20I4), Statistical Reports, http://www.tbb.org.tr/tr/Banka_ve_Sektor_Bilgileri/Tum_ Raporlar.aspx (15.04.2014)

Central Bank of the Republic of Turkey (CBRT) (20I4), Electronic Data Distribution System, http://evds.tcmb.gov.tr/cbt.html (30.04.2014)

Change in Banking Leverage Ratio also presents negative Granger Causality over GDP Growth Rate with each numbers of lag. Levels of probability in models indicate that results are statistically significant.

\subsection{I.3.GDP Growth Rate and Credit Growth Rate}

One of the most important credit indicators is credit growth; the test results for this variable are given below Table 5 . 
Table 5: Granger Causality Test Results for GDP and Credit Growth Rate

\begin{tabular}{|c|c|c|c|c|}
\hline \multicolumn{5}{|c|}{ Dependent variable: GDP } \\
\hline Excluded & Chi-sq & Negative/Positive (Coefficients) & Lag Number & Probability \\
\hline $\mathrm{D}($ Credit $)$ & 2.478673 & $(-)$ & 1 & 0.1154 \\
\hline $\mathrm{D}($ Credit $)$ & 4.252193 & $(-)$ & 2 & 0.1193 \\
\hline $\mathrm{D}($ Credit $)$ & 5.437542 & $(-)$ & 3 & 0.1424 \\
\hline $\mathrm{D}($ Credit $)$ & 4.798962 & $(-)$ & 4 & 0.3086 \\
\hline $\mathrm{D}($ Credit $)$ & 3.151110 & $(-)$ & 5 & 0.6767 \\
\hline
\end{tabular}

*, **, Parameters are statistically significant by $\% 99$ and $\% 95$ confidence intervals.

\section{Source:}

Banking Regulation and Supervision Agency of Turkey (BRSA) (2014), Statistical Data, http://www.bddk.org.tr/WebSitesi/ turkce/lstatistiki_Veriler/lstatistiki_Veriler.aspx (15.04.2014)

Turkish Banking Association (TBA) (2014), Statistical Reports, http://www.tbb.org.tr/tr/Banka_ve_Sektor_Bilgileri/Tum_ Raporlar.aspx (I5.04.20I4)

Central Bank of the Republic of Turkey (CBRT) (2014), Electronic Data Distribution System, http://evds.tcmb.gov.tr/cbt.html (30.04.2014)

As it is seen from the above, there is no statistically significant consequence for GDP and credit growth model.

\subsection{I.4.GDP Growth Rate and Credit/Deposit Ratio}

Credit/Deposit is one of the most important ratios used in financial analysis of banks since it is calculated from the two most important items balance sheet of banks. Thus, it is one of the main financial intermediaries and credit indicators too. Granger Test results of GDP and Credit/ Deposit are below Table 6.

Table 6: Granger Causality Test Results for GDP and Credit/Deposit Ratio

\begin{tabular}{|c|c|c|c|c|}
\hline \multicolumn{5}{|c|}{ Dependent variable: GDP } \\
\hline Excluded & Chi-sq & Negative/Positive (Coefficients) & Lag Number & Probability \\
\hline $\mathrm{D}$ (CreDep) & 0.572090 & $(+)$ & 1 & 0.4494 \\
\hline $\mathrm{D}($ CreDep) & 0.904467 & $(+)$ & 2 & 0.6362 \\
\hline $\mathrm{D}($ CreDep) & 1.729773 & $(+)$ & 3 & 0.6303 \\
\hline $\mathrm{D}($ CreDep) & 3.730288 & $(-)$ & 4 & 0.4437 \\
\hline $\mathrm{D}($ CreDep) & 5.783028 & $(-)$ & 5 & 0.3279 \\
\hline
\end{tabular}

*, **, Parameters are statistically significant by $\% 99$ and $\% 95$ confidence intervals.

\section{Source:}

Banking Regulation and Supervision Agency of Turkey (BRSA) (20I4), Statistical Data, http://www.bddk.org.tr/WebSitesi/ turkce/Istatistiki_Veriler/lstatistiki_Veriler.aspx (I5.04.20I4)

Turkish Banking Association (TBA) (2014), Statistical Reports, http://www.tbb.org.tr/tr/Banka_ve_Sektor_Bilgileri/Tum_ Raporlar.aspx (15.04.20I4)

Central Bank of the Republic of Turkey (CBRT) (20I4), Electronic Data Distribution System, http:/levds.tcmb.gov.tr/cbt.html (30.04.2014) 
As it is seen from results, there is no statistically significant relationship between GDP and credit/deposit.

\subsection{I.5.GDP Growth Rate and Non-performing Loans Ratio}

NPL Ratio is not only one of the main asset quality indicators for banks, but also provides strong signals for credit policy and strategy of banks, so it is another important credit indicator for banks and real economy. The extent of the relationship between NPL and GDP is another interesting point for modeling. Test results of this model are below Table 7.

Table 7: Granger Causality Test Results for GDP and NPL Ratio

\begin{tabular}{|c|c|c|c|c|}
\hline \multicolumn{5}{|c|}{ Dependent variable: GDP } \\
\hline Excluded & Chi-sq & $\begin{array}{c}\text { Negative/Positive } \\
\text { (Coefficients) }\end{array}$ & Lag Number & Probability \\
\hline $\mathrm{D}(\mathrm{NPL})$ & 0.003551 & $(+)$ & 1 & 0.9525 \\
\hline $\mathrm{D}(\mathrm{NPL})$ & 0.454089 & $(+)$ & 2 & 0.7969 \\
\hline $\mathrm{D}(\mathrm{NPL})$ & 2.163512 & $(-)$ & 3 & 0.5392 \\
\hline $\mathrm{D}(\mathrm{NPL})$ & 2.522570 & $(-)$ & 4 & 0.6406 \\
\hline $\mathrm{D}(\mathrm{NPL})$ & 1.834165 & $(-)$ & 5 & 0.8716 \\
\hline
\end{tabular}

*, **, Parameters are statistically significant by $\% 99$ and $\% 95$ confidence intervals.

Source:

Banking Regulation and Supervision Agency of Turkey (BRSA) (20I4), Statistical Data, http://www.bddk.org.tr/WebSitesi/ turkce/lstatistiki_Veriler/lstatistiki_Veriler.aspx (I5.04.20I4)

Turkish Banking Association (TBA) (20I4), Statistical Reports, http://www.tbb.org.tr/tr/Banka_ve_Sektor_Bilgileri/Tum_ Raporlar.aspx (15.04.2014)

Central Bank of the Republic of Turkey (CBRT) (20I4), Electronic Data Distribution System, http://evds.tcmb.gov.tr/cbt.html $(30.04 .2014)$

Again, there is no statistically significant consequence for GDP and NPL model.

\subsubsection{Current Account Balance and Credit Indicators}

Current Account Balance/GDP (CAB) is another dependent variable in our analysis. Same credit indicators are examined with $\mathrm{CAB}$ in order to display effects of credit over current account.

\subsubsection{I.Current Account Balance/GDP and Banking Leverage Ratio}

As GDP models, banking leverage is our first credit indicator to analyze with CAB. Granger Causality Test results between CAB and leverage are given below Table 8 . 
Table 8: Granger Causality Test Results for CAB and Banking Leverage Ratio

\begin{tabular}{|c|c|c|c|c|}
\hline \multicolumn{5}{|c|}{ Dependent variable: CAB } \\
\hline Excluded & Chi-sq & Negative/Positive (Coefficients) & Lag Number & Probability \\
\hline Lev & 7.639264 & $(+)$ & 1 & $0.0057^{\star}$ \\
\hline Lev & 13.83139 & $(+)$ & 2 & $0.0010^{*}$ \\
\hline Lev & 19.49783 & $(+)$ & 3 & $0.0002^{\star}$ \\
\hline Lev & 25.12353 & $(+)$ & 4 & $0.0000^{*}$ \\
\hline Lev & 34.91555 & $(+)$ & 5 & $0.0000^{*}$ \\
\hline
\end{tabular}

*, **, Parameters are statistically significant by $\% 99$ and $\% 95$ confidence intervals.

\section{Source:}

Banking Regulation and Supervision Agency of Turkey (BRSA) (20I4), Statistical Data, http://www.bddk.org.tr/WebSitesi/ turkce/Istatistiki_Veriler/Istatistiki_Veriler.aspx (I5.04.20I4)

Turkish Banking Association (TBA) (2014), Statistical Reports, http://www.tbb.org.tr/tr/Banka_ve_Sektor_Bilgileri/Tum_ Raporlar.aspx (15.04.2014)

Central Bank of the Republic of Turkey (CBRT) (20I4), Electronic Data Distribution System, http://evds.tcmb.gov.tr/cbt.html $(30.04 .2014)$

Banking Leverage Ratio provides positive Granger causality over CAB for each numbers of lag in our model. Also low levels of probability show that the relationship between variables is statistically significant.

\subsubsection{Current Account Balance/GDP and Change in Banking Leverage Ratio}

Change in leverage is another credit indicator modeled with CAB. Test results are given below Table 9.

Table 9: Granger Causality Test Results for CAB and Change in Banking Leverage Ratio

\begin{tabular}{|c|c|c|c|c|}
\hline \multicolumn{5}{|c|}{ Dependent variable: CAB } \\
\hline Excluded & Chi-sq & Negative/Positive (Coefficients) & Lag Number & Probability \\
\hline ChgLev & 0.091848 & $(+)$ & 1 & 0.7618 \\
\hline ChgLev & 7.805741 & $(+)$ & 2 & $0.0202^{\star *}$ \\
\hline ChgLev & 9.846076 & $(+)$ & 3 & $0.0199^{* *}$ \\
\hline ChgLev & 13.52404 & $(+)$ & 4 & $0.0090^{*}$ \\
\hline ChgLev & 20.92399 & $(+)$ & 5 & $0.0008^{*}$ \\
\hline
\end{tabular}

*, **, Parameters are statistically significant by $\% 99$ and $\% 95$ confidence intervals.

\section{Source:}

Banking Regulation and Supervision Agency of Turkey (BRSA) (20I4), Statistical Data, http://www.bddk.org.tr/WebSitesi/ turkce/lstatistiki_Veriler/lstatistiki_Veriler.aspx (15.04.2014)

Turkish Banking Association (TBA) (20I4), Statistical Reports, http://www.tbb.org.tr/tr/Banka_ve_Sektor_Bilgileri/Tum_ Raporlar.aspx (15.04.20I4)

Central Bank of the Republic of Turkey (CBRT) (20I4), Electronic Data Distribution System, http://evds.tcmb.gov.tr/cbt.html $(30.04 .2014)$ 
As it seen from the results, change in leverage has positive effect over CAB except 1 number of lag in our model. Additionally, low levels of probability present statistically significant relationship between variables.

\subsubsection{Current Account Balance/GDP and Credit Growth Rate}

Total credit growth is one of the most controversial topics in the subject of macro prudential measures in order to sustain financial stability. Therefore, the function of credit growth over current account balance is usually argued by policymakers and academics. The test results for the model to measure Granger causality between two variables are given below Table 10.

Table 10: Granger Causality Test Results for CAB and Credit Growth Rate

\begin{tabular}{|c|c|c|c|c|}
\hline \multicolumn{5}{|c|}{ Dependent variable: CAB } \\
\hline Excluded & Chi-sq & $\begin{array}{c}\text { Negative/Positive } \\
\text { (Coefficients) }\end{array}$ & Lag Number & Probability \\
\hline $\mathrm{D}$ (Credit) & 8.513917 & $(-)$ & 1 & $0.0035^{\star}$ \\
\hline $\mathrm{D}$ (Credit) & 0.335779 & $(-)$ & 2 & 0.8454 \\
\hline $\mathrm{D}$ (Credit) & 0.116236 & $(-)$ & 3 & 0.9898 \\
\hline $\mathrm{D}$ (Credit) & 0.554838 & $(-)$ & 4 & 0.9679 \\
\hline $\mathrm{D}$ (Credit) & 0.266024 & $(-)$ & 5 & 0.9982 \\
\hline
\end{tabular}

*, **, Parameters are statistically significant by $\% 99$ and $\% 95$ confidence intervals.

\section{Source:}

Banking Regulation and Supervision Agency of Turkey (BRSA) (2014), Statistical Data, http://www.bddk.org.tr/WebSitesi/ turkce/lstatistiki_Veriler/lstatistiki_Veriler.aspx (I5.04.20I4)

Turkish Banking Association (TBA) (20I4), Statistical Reports, http://www.tbb.org.tr/tr/Banka_ve_Sektor_Bilgileri/Tum_ Raporlar.aspx (15.04.20I4)

Central Bank of the Republic of Turkey (CBRT) (20I4), Electronic Data Distribution System, http://evds.tcmb.gov.tr/cbt.html (30.04.2014)

According to model results, credit growth has negative effect over CAB for just 1 number of lag in our model. Granger causality for other numbers of lag is not statistically significant.

\subsection{I.4.Current Account Balance/GDP and Credit/Deposit Ratio}

Credit/Deposit Ratio is another explanatory variable modeled with CAB and test results are presented below Table 11. 
Table I I: Granger Causality Test Results for CAB and Credit/Deposit Ratio

\begin{tabular}{|c|c|c|c|c|}
\hline \multicolumn{5}{|c|}{ Dependent variable: CAB } \\
\hline Excluded & Chi-sq & Negative/Positive (Coefficients) & Lag Number & Probability \\
\hline $\mathrm{D}($ CreDep) & 26.88327 & $(-)$ & 1 & $0.0000^{*}$ \\
\hline $\mathrm{D}($ CreDep) & 8.724075 & $(-)$ & 2 & $0.0128^{* *}$ \\
\hline $\mathrm{D}($ CreDep) & 8.646847 & $(-)$ & 3 & $0.0344^{* *}$ \\
\hline $\mathrm{D}($ CreDep) & 19.76508 & $(-)$ & 4 & $0.0006^{*}$ \\
\hline $\mathrm{D}($ CreDep) & 21.71700 & $(-)$ & 5 & $0.0006^{*}$ \\
\hline
\end{tabular}

*, **, Parameters are statistically significant by $\% 99$ and $\% 95$ confidence intervals.

\section{Source:}

Banking Regulation and Supervision Agency of Turkey (BRSA) (2014), Statistical Data, http://www.bddk.org.tr/WebSitesi/ turkce/Istatistiki_Veriler/Istatistiki_Veriler.aspx (I5.04.20I4)

Turkish Banking Association (TBA) (2014), Statistical Reports, http://www.tbb.org.tr/tr/Banka_ve_Sektor_Bilgileri/Tum_ Raporlar.aspx (15.04.2014)

Central Bank of the Republic of Turkey (CBRT) (20I4), Electronic Data Distribution System, http:/levds.tcmb.gov.tr/cbt.html $(30.04 .2014)$

Credit/Deposit Ratio has negative Granger causality over CAB with each number of lag in our model. Besides, low probabilities indicate statistically significant relationship between variables.

\subsection{I.5.Current Account Balance/GDP and Non-performing Loans Ratio}

The last credit indicators modeled with CAB is NPL and test results are given below Table 12.

Table I 2: Granger Causality Test Results for CAB and NPL Ratio

\begin{tabular}{|c|c|c|c|c|}
\hline \multicolumn{5}{|c|}{ Dependent variable: CAB } \\
\hline Excluded & Chi-sq & Negative/Positive (Coefficients) & Lag Number & Probability \\
\hline D(NPL) & 8.099270 & $(+)$ & 1 & $0.0044^{*}$ \\
\hline D(NPL) & 3.259734 & $(-)$ & 2 & 0.1960 \\
\hline D(NPL) & 2.116110 & $(-)$ & 3 & 0.5487 \\
\hline D(NPL) & 9.203111 & $(+)$ & 4 & 0.0562 \\
\hline D(NPL) & 6.936934 & $(+)$ & 5 & 0.2254 \\
\hline
\end{tabular}

*, **, Parameters are statistically significant by $\% 99$ and $\% 95$ confidence intervals.

\section{Source:}

Banking Regulation and Supervision Agency of Turkey (BRSA) (20I4), Statistical Data, http://www.bddk.org.tr/WebSitesi/ turkce/lstatistiki_Veriler/Istatistiki_Veriler.aspx (I5.04.20I4)

Turkish Banking Association (TBA) (20I4), Statistical Reports, http://www.tbb.org.tr/tr/Banka_ve_Sektor_Bilgileri/Tum_ Raporlar.aspx (15.04.2014)

Central Bank of the Republic of Turkey (CBRT) (20I4), Electronic Data Distribution System, http://evds.tcmb.gov.tr/cbt.html $(30.04 .2014)$ 
NPL has positive causality over CAB for just 1 number of lag in our model. Granger causality for other numbers of lag is not statistically significant.

\section{Conclusions and Policy Implications}

Considerable findings and implications derived from results of our analysis and models are summarized below:

- Credit indicators are more related to and present more causality over Current Account Balance/GDP than GDP Growth Rate.

- Banking Leverage is more related to and presents more causality over current account balance and GDP compared to other credit indicators.

- Banking Leverage exhibits interestingly negative causality with GDP and positive causality with current account balance.

- Credit Deposit Ratio, known as one of the most important indicators of financial intermediary and credit expansion, shows negative causality with current account balance.

- Credit Growth Rate, another important indicator of credit expansion, does not provide any causality with GDP growth and shows limited negative causality for current account balance.

- NPL does not have any causality with GDP and it has slight one with current account balance, because it is generally a consequence from the macroeconomic environment.

As for the policy implications, our findings exhibit that banking leverage is more effective regulation and policy tool as macro prudential measures than other credit indicators. Leverage is more comprehensive indicator for both general economy and banking activities relative to essential indicators of credit growth and expansion.

High banking leverage can increase vulnerabilities in economic activities; on the other hand it can support current account balance. Therefore, monitoring and analyzing level of banking leverage is essential in terms of financial and macro economical stabilities. 


\section{References}

AKÇELIKK Yasin, ERMIŞ̧OGLU Ergun and ODUNCU Arif (2013), GDP Growth and Credit Data, Central Bank of the Republic of Turkey Working Paper No: 13/27, July 2013

AMRI Puspa D., PRABHA Apanard P. And WIHLBORG Clas (2012), What Makes High Credit Growth Harmful? Evidence from Banking Crises, December 7, 2012 http://papers.ssrn.com/sol3/papers. cfm?abstract_id=2186569 (15.11.2013)

ELEKDAĞ Selim and WU Yiqun (2011), Rapid Credit Growth: Boon or Boom-Bust?, IMF Working Paper, WP/11/241, October 2011

GANİĞLU Aytül (2013), Rapid Credit Growth and Current Account Deficit as the Leading Determinants of Financial Crises, Discussion Paper, No. 2013-35, July 08, 2013, http://www.economics-ejournal. org/economics/discussionpapers/2013-35 (15.02.2014)

JORDA Òscar, SCHULARICK Moritz, and TAYLOR Alan M. (2010), Financial Crises, Credit Booms, And External Imbalances:140 Years Of Lessons, NBER Working Paper 16567, December 2010, http:// www.nber.org/papers/w16567 (15.02.2014)

JORDA Òscar, SCHULARICK Moritz, and TAYLOR Alan M. (2011), When Credit Bites Back: Leverage, Business Cycles, And Crises, NBER Working Paper Series, Working Paper 1762, November 2011, http://www.nber.org/papers/w17621 (15.02.2014)

KAMINSKY Graciela and REINHART Carmen (1999), The twin crises: The causes of banking and balance of payments problems, Munich Personal RePEc Archive, MPRA Paper No. 14081, June 1999, http://mpra.ub.uni-muenchen.de/14081/ (18.03.2014)

LANE Philip R. and MCQUADE Peter (2013), Domestic Credit Growth and International Capital Flows, European Central Bank, Working Paper Series, No 1566, July 2013

LEITAO Nuno Carlos (2012), Bank Credit and Economic Growth: A Dynamic Panel Data Analysis, The Economic Research Guardian, Vol. 2(2) 2012, 256-267, http://works.bepress.com/nuno_leitao/10 (01.04.2014)

NUNO Galo and CARLOS Thomas (2013), Bank Leverage Cycles, European Central Bank, Working Paper Series, No 1524, March 2013

SCHULARICK Moritz and TAYLOR Alan M. (2009), Credit Booms Gone Bust: Monetary Policy, Leverage Cycles And Financial Crises 1870-2008, National Bureau Of Economic Research (NBER), Working Paper 15512, November 2009, http://www.nber.org/papers/w15512 (15.04.2014)

TAYLOR Alan M. (2012), The Great Leveraging, University of Virginia, NBER, and CEPR, July 2012 http://www.bis.org/events/conf120621/taylor.pdf (30.04.2014)

TELATAR Erdinç (2011), Türkiye’de Cari Açık Belirleyicileri ve Cari Açık-Krediler İlişkisi, TBB Bankacılar Dergisi, Sayı 78, 2011, 22-34

TİRYAKİ Göksel (2010), Bankacılık Sektöründe -Basel Sermaye Uzlaşıları- Sermaye Yeterliliği Standart Rasyosu Gerçekten Yeterli Midir? Kaldıraç Oranına ve Daha Güçlü Bir Bankacılık Düzenleme Çerçevesine İlişkin Değerlendirmeler, Vergi Dünyası Dergisi, 347. Sayı, Temmuz 2010, 118-122

TİRYAKİ G. (2012), Finansal İstikrar ve Bankacılık Düzenlemeleri (1990-2010 Türkiye Tecrübesi Işı̆̆ında), Türkiye Bankalar Birliği, Kasım 2012

TAKATS Előd and UPPER Christian (2013), Credit and growth after financial crises, BIS Working Papers No 416, BIS Monetary and Economic Department, July 2013 


\section{Websites}

MILES David (2011), What is The Optimal Leverage for a Bank, VOX, April 2011, http://www.voxeu.org/ article/what-optimal-leverage-bank (15.04.2014)

Banking Regulation and Supervision Agency of Turkey (BRSA) (2014), Statistical Data, http://www.bddk. org.tr/WebSitesi/turkce/Istatistiki_Veriler/Istatistiki_Veriler.aspx (15.04.2014)

Turkish Banking Association (TBA) (2014), Statistical Reports, http://www.tbb.org.tr/tr/Banka_ve_Sektor_ Bilgileri/Tum_Raporlar.aspx (15.04.2014)

Central Bank of the Republic of Turkey (CBRT) (2014), Electronic Data Distribution System, http://evds. tcmb.gov.tr/cbt.html (30.04.2014)

CAMPOS Nauro F. and DERCON Stefan (2014), Gaps, Cracks and Lacunae: The Finance and Growth Nexus in Low-Income Countries, VOX, March 2014, http://www.voxeu.org/article/finance-andgrowth-nexus-low-income-countries (30.04.2014) 